\title{
Gazali ve Benötesi Yaklaşım
}

\author{
ÖZNUR ÖZDOĞAN \\ DOÇ. DR., ANKARA ÜNIVERSITESI
}

\begin{abstract}
Özet
Gazali insan hayatındaki en önemli dönüşüm olan kendini keşfetme sürecini yaşamıştır. Transpersonel yaklaşım Gazali’nin bu tecrübesini “ holotropik şuur hali” olarak açıklar.

Gazal' nin yaşadığı fiziksel ve psikolojik sorunlar ben ötesi yaklaşımda ruhsal olgunlaşmayı sağlayan psikospiritüel krizler olarak isimlendirilmektedir. Bu deneyimleri Gazali' nin hastalıklar ile ilgili görüşlerini oluşturmuştur. Gazali'ye göre kendi amacı dışında işleyen bir organ hastadır. Psikolojik problemlerin sebebi kalp ve aklın kendi amacı dışında kullanılmasıdır. Ona göre kendi bedensel varlığımız dâhil olmak üzere tüm görünen alem, bireyin gerçek kimliğini bulması için birer aracı rolündedir.
\end{abstract}

\begin{abstract}
Ghazali and Transpersonal approach

Human beings finding his own fact on his own walking road and as all human being through self-expression communicating with other people is to know firstly himself. Ghazali lived the process of inquiry himself that is an important phase of transformation in his life. Transpersonal approach explains Ghazali's this experience as 'holotropik state of consciousness".

Ghazali declared his illness and health status with a specific spiritual approach. According to Ghazali, an organ working outside its own aim gets sick. The reason of psychological problems is also to use mind and hearth outside their aim. A person who has anything more delightful than God is a sick person. According to Ghazali, the healtiest person, in spiritual sense, is Prophet Muhammad. Science, aspect and deed circle about which Ghazali talked, introduce the principle of Cognitive Psychology's viewpoint, that is one of the most popular therapy methods of modern science of psychology.
\end{abstract}




\section{Giriş}

Transpersonel-benötesi psikoloji, öncelikle her insanın derinliklerinde, genelde bilinen, güncel hayata yansıyan yönünden daha yüce bir yönü, olduğuna inanır. İnsanı sonsuz gelişme potansiyeli olan bir varlık olarak kabul eder ve bitmiş değil, gelişme halinde bir ekoldür. Benötesi deneyimler, tanımları itibarıyla kimlik duygusu ve benlik kavramını aşar. İnsanlığın maneviyatını ve daha geniş yönlerini ihtiva eder. ${ }^{1}$

1950'lerde psikoterapistler, yeni bir hasta tipiyle karşılaşmaya başladılar. Bu tip, çağdaş toplumsal standartlara göre gayet normal kabul edilen, başarılı bir kişidir. Saygın bir mesleğe, makul bir gelire, makul bir aile yaşamına, toplum içinde saygınlığa, yani toplumda insana mutluluk getireceğine inanılan tüm olanaklara sahiptir. Bu kişi, sıradan standartlara göre "mutlu" olduğunu bilir, ancak yine de terapiye başvurur, çünkü yaşamın boş olduğunu düşünmekte ve kendini mutsuz hissetmektedir. Yaşamda para, kariyer, mal ve itibardan daha fazlası yok mudur? Hayatın anlamı nerededir? ${ }^{2}$

Geleneksel terapide, kişilik yapısındaki sorunlar tespit edilip düzeltilebilir, kişiliği geliştirme yönünde yol gösterilebilir ancak asıl soruna, yani yaşamın "derin anlamı" sorununa pek değinilmez.

"Başarılı-doyumsuz" olarak adlandıracağımız bu tiplerin ortaya çıkması hümanist-insancıl psikoloji ve transpersonel-benötesi psikolojinin gelişimini tetiklemiştir. Bu psikoloji okulları, sıradan yaşam ve buna ayak uydurmaya çaıışan kişilik tipleri hakkındaki bilgi birikiminin yararlarını kabul ediyor, ancak buna ek olarak insanlığın özünde, varoluşsal ve manevi bir boyut olduğunu da görüyorlardı. Sıradan düzeyde bir yaşam için gereken becerileri geliştirmede makul bir başarıya ulaşıldığında, kişi mutlu ve sağlıklı olmak istiyorsa varoluşsal ve manevi boyutlarda da kendini geliştirmek zorundayd $1{ }^{3}$

İnsanın manevi ve ben ötesi boyutlarına ilk açılımı getiren Jung'dır. Daha sonra Rogers, Maslow, Fromm insanın aşkın boyutuna yönelik çalışmalar yapmışlardır. Doğu öğretilerinin modern Batılılar tarafından kullanılması için uyarlanmasına öncülük eden G.I. Gurdjieff Enneagram kuramını geliştirmiş-

1 Ayten, Ali, “Transpersonel Psikoloji Nedir Ne Değildir”, Din Psikolojisi, İz Yayıncıllk, İstanbul 2010, s.97-98.

2 Palmer, Helen, Ruhun Aynası Enneagram'a Yansıyan İnsan Manzaraları, Kaknüs Yayınları, 2006, s.9.

3 Palmer, Helen, Ruhun Aynası Enneagram'a Yansiyan İnsan Manzaraları, s.10 
tir. Bu, kendini tanıma sistemi ve kişilik üzerine bir kuramdır: ${ }^{4}$ Her canlının içinde kendisi olma dürtüsü vardır. Tırtılın kelebeğe dönüşeceğinin, kozalağın meşe ağacına dönüşeceğinin bilgisi, tırtılın ve kozalağın içindedir. Bu bilgi başlangıçta sadece potansiyel olarak vardır. Potansiyel, kendiliğinden ortaya çıkmaz. Her canlının öncelikle potansiyelini ortaya çıkaracak koşullar içinde olması gerekir. Kozalağın toprak, su ve güneş ortamına ihtiyaç duyması gibi. Sonra gelişmesi ve kendisini ifade etmesi için belirli süreçlerden geçmeyi göze alması gerekir. Tırtılın koza örmesi ve kelebeğe dönüşmek için ayaklarından ve kozanın güvenliğinden vazgeçmesi gibi.

İnsanın kendi yürüdügü yolda kendi gerçeğini bulması, bütün bir insan olarak kendini ifade ederek diğer insanlarla sağliklı iletişim kurması öncelikle kendisini tanımaktan geçmektedir. Enneagram, yaşam boyu süren kendimizi keşfetme sürecinde bize tipimize ilişkin tuzakları ve zaafları göstererek, kendi öz doğamıza daha derinden bakmamızı sağlar. Bu çalışma, tipimizin otomatik tepkilerine dur diyerek, içgörü kazanmamızı sağlar ve uykuda yaşamak yerine uyanmamızı amaçlar. Kişilik tipimizin otomatik tepkilerini ne kadar çok görürsek, onlarla özdeşleşmekten o kadar vazgeçeriz. Kendimiz olmak ve özgürleşmek böyle ifade edilebilir. ${ }^{5}$

Gazali hayatındaki önemli bir dönüşüm evresi olan kendini sorgulama sürecinin başlangıcında kendini şöyle ifade etmektedir:

"Vakta ki, bu vesveseler içime doğdu ve kalbimde yer etti, bu defa buna ilâç aramaya koyuldum. Fakat bu kolay olmadı. Çünkü bu hastalığın tedavisi ancak delil ile mümkün olabilirdi. Bir delilin ikamesi de ancak ulûm-i evvelin dediğimiz bilgilerden meydana gelir. Bu da müsellem- kabul edilmiş olmazsa delil yapmak da mümkün olmaz. Bu suretle hastalığın giderilmesine imkân bulunmadı. Bu hal böylece iki aya yakın devam etti. Bu müddet içinde, manen ve hal ile safsata yolunda bulundum ise de lâfzan bunu açıklamıyordum. Nihayet Cenabı Hakk beni bu hastalıktan kurtardı. Nefsim sıhhat ve itidal haline avdet etti. Aklî zaruretler emniyet ve yakîn üzere makbul ve itimada şayan olarak rücu' etti. Bu seziş ve bu safsatadan kurtuluş bir delil veya bir istidlal tertibi ile değil, ancak Allah'ın kalbime ilka' ettiği bir nur ile olmuştur. Bu nur, birçok bilgi kapılarının anahtarıdır. Her kim bir şeyin hakikatini keşf ve mânasının sırf delillere bağlı olduğunu

4 Palmer, Helen, Ruhun Aynası Enneagram'a Yansiyan İnsan Manzaraları, s.6-8

5 Palmer, Helen, Ruhun Aynası Enneagram'a Yansıyan İnsan Manzaraları, s.12-14 
zannederse, muhakkak ki, Allah'ın geniş ve sonsuz rahmetini daraltmış olur. Ayet-i Kerîme'de:

«Allahü Tealâ kimin hidayetini murad ederse, İslâm için kalbini şerh eder...» buyrulmuştur. Bu ayette geçen şerh kelimesinden muradın ne olduğu $\mathrm{Hz}$. Peygamberden sorulunca:

- O, Allahü Tealâ'nın kalbe ilka ettiği bir nurdur, buyurdular."’

Transpersonel-benötesi yaklaşım, Gazali' nin bu deneyiimini "holotropik şuur hali” olarak açıklamaktadır: Günlük şuur hallerimizde gerçekte olduğumuzun ancak küçük bir parçasıyla özdeşleşiriz. Holotropik durumlarda ise beden, egosunun dar sınırlarını aşabilir, tam kimliğimizi kullanılabilir bir hale gelebiliriz. Holotropik durumlarda şuur niteliksel olarak oldukça derin ve temel bir biçimde değişime uğrar ama nedenlerin organik olduğu koşullardaki kadar, büyük ölçülerde bozulmaz. Uzay ve zaman açısından genellikle oryantasyonumuz tam olarak aynı kalır ve günlük gerçeklikle bağımızı tam olarak yitirmeyiz. Aynı zamanda, şuur alanımıza başka varoluş boyutlarından gelen içerikler girebilir, bu oldukça yoğun hatta karşı konulamaz bir biçimde meydana gelebilir. Bu yüzden aynı anda oldukça farklı iki gerçekliği yaşarız, 'iki ayăğımız da farklı bir dünyadadır. ${ }^{7}$

Holotropik şuur halini yaşamada mekan önemli görülmektedir: Bir mağarada, çölde, buzulda veya yüksek dağlarda kalmak gibi uzun süreli sosyal ve duyusal yalıtım da holotropik durumların başlatılmasının araçları olarak önemli bir rol oynarlar. Gazali gerçeği keşfetme sürecini Emevi camiinde geçirdiğini şöyle anlatmaktadır: "Bir müddet Şam'daki Emevî Camiinde itikâfa girmiştim. Her gün caminin minaresine çıkar, kapıyı üzerime kilitlerdim. ${ }^{8}$

Transpersonel-benötesi yaklaşıma göre ruhsal bir krizin belirtileri ile psikolojik krizin belirtileri neredeyse aynıdır. Ruhsal bir kriz doğal olarak benlik ile ilgilidir. Ruhsal kriz yaşadığımız süreçte, varoluşumuzun ve yaşantılarımızın anlamı, en temel sorudur. Kendimizi hayatın öğreticiliğine açarak, yaşadığımız olayların tesadüf olmadığını anlamak önemli bir farkındalıktır. Gazali yaşadığı psiko-spritüel kriz sürecini şöyle kelimelere dökmektedir: Kendi hallerimi düşündüm. Bir de baktım ki, dünya alâkalarının içine dalmışım. Bu

6 Gazali, El Munkızu Mined Dalâl, Çağaloğlu Yayınevi, 1984, s.17-18.

7 Grof, Stanislav, Geleceğin Psikolojisi, Ege Meta Yayınları, 2000, İzmir, s .22

8 Gazali, El Munkızu Mined Dalâl, s.63. 
alâkalar beni her taraftan sarmış. Yaptığım işleri gözümün önüne getirdim. Onların en güzeli tedris ve ta'lim idi. Burada da ehemmiyetsiz, ahiret yoluna pek faydası olmayan bir takım ilimlerle meşgul olduğumu anladım. Sonra tedris hakkındaki niyetimi yokladım. Onun da Allah rızası için olmadığını, mevki sahibi olmak, şan, şeref ve şöhret kazanmak peşinde olduğuma kanaat getirdim. Uçurumun kenarında bulunduğumu, eğer kaybettiğim hallerimi düzeltmekle meşgul olmazsam ateşe yuvarlanacağımı anladım. Bir müddet düşündüm, kaldım. Henüz bir neticeye varmış değildim, düşünüyordum ve kurtulabilirdim... Bir gün Bağdat'dan çıkmağa ve bu hallerden ayrılmağa karar verir, ertesi gün verdiğim bu karardan vazgeçerdim. Tamamen kararsızlık içinde idim. Sabahleyin ahirete karşı istek ve arzum kuvvet bulsa akşamüzeri dünya arzuları kalabalık bir ordu halinde saldırarak bu arzuyu dağıtırdı. Bu suretle dünya arzularının zincirleri beni makama doğru çekiyordu. İman münadisi ise bana şöyle sesleniyordu: “Göç'e hazırlan göç'e! Geride ömrünün pek azı kalmıştır. Önünde uzun bir ahiret yolculuğu var. Bugüne kadar elde ettiğin bütün ilim ve amel hep riya ve gösteriştir. Şimdi ahiret için hazırlık yapmazsan ne zaman hazırlanacaksın? Dünya ile alâkanı şimdi kesmezsen ne zaman keseceksin?” Bundan sonra içimde Bağdat’tan kaçıp uzaklaşmak arzusu kuvvet bulurdu. Bu sefer de şeytan gelerek şöyle derdi: "Sana gelen bu hal geçicidir. Sakın ona aldanıp itaat etme. Çünkü o, çabuk geçer. Şayet ona uyarak bu büyük mevkii, hiç kimsenin bozamayacağı muntazam hayatı ve düşmanların tarafindan dahi bozulmak tehlikesinden uzak olan bu yaşayışı terk edersen, ihtimal ki nefsin onu günün birinde arzu eder, fakat bu hayatı tekrar elde etmek kolay olmaz." Gelip giden talebelerimi memnun etmek için bir gün olsun ders vermeğe kendimi zorluyordum. Fakat dilim bir kelime dahi söyleyemez olmuştu. Buna gücüm yetmiyordu. Sonra dilimdeki bu tutukluk dolayısıyla kalbime bir hüzün çöktü. Bunun tesiriyle de yediğimi hazmedemez oldum. Yemeden içmeden kesildim. Ne bir yudum su içebiliyor, ne de bir lokmayı midem hazmediyordu. Bu yüzden bütün bedenî kuvvetlerim zayıf düştü. Hattâ hekimler ilâçla tedaviden ümitlerini kestiler.

Dediler ki:

« Bu, kalpte meydana gelen bir haldir. Buradan mizaca sirayet etmiştir.

Kalbe arız olan bu elem ve hüzün giderilmedikçe, bunun ilâçla tedavi edilmesine imkân yoktur.» 
Sonra aczimi hissederek ihtiyarım tamamen elden gidince çaresiz kalmış bir kimsenin sığındığı gibi ben de Allah'a sığındım. Çaresiz kullarının duasını karşıılıksız bırakmayan Allah beni kurtardı. ${ }^{9}$

İnsanlardan ayrı yaşadığım müddet 11 seneyi bulmuştur. Bu, Allah'ın takdir ettiği bir harekettir. Bu hareket Cenabı Hakkın takdirlerinden biridir ki, Bağdat' tan çıkışım ve uzlet hallerinden ayrılışım, bu uzlet zamanında nasıl imkânı hatırı hayale gelmeyen şeylerdense, bu takdir de öylece hayalimden geçmeyen şeylerdendi. Kalblerde, hallerde değişiklik yapan Allah'tır. Ben o zamanlar insana rütbe ve mevki kazandıran ilmi yayıyordum. Sözümle, amelimle ona davet ediyordum. Maksadım, niyetim hep mevki ve şeref kazanmaktı. Şimdi ise mevkii, rütbeyi terk ettiren ve bunlardan uzaklaşmay1 öğreten ilme davet ediyordum. Allah biliyor ki, şimdiki niyetim, maksadım, arzum budur. Ben kendimi ve başkasını islah etmek istiyorum. Ama maksadıma erişir miyim; yoksa muradıma ermekten mahrum mu kalırım? Onu bilemem. Lâkin ma'siyet halinden dönüş ve taata yönelişin, ancak Allah Azimüşşandan olduğuna yakîn ve müşahede derecesine varan bir iman ile inaniyorum. Ben hareket etmedim, fakat Allah beni harekete getirdi. Ben bir amel işlemedim, $\mathrm{O}$ bana yaptırdı. $\mathrm{O}$ halde evvelâ beni ıslah etmesini, sonra benim vasıtamla başkasını doğru yola ulaştırmasını O'ndan niyaz ediyorum. Bana hakkı hak gösterip ona uymayı, batılı batıl gösterip, ondan kaçınmak çaresini ihsan etmesini diliyorum." 10

Yüksek şuur hallerinin gerçekleştiği süreçte ani ruhsal aç1lımlar meydana gelmektedir. Transpersonel-benötesi yaklaşıma göre, günümüzde psikotik olarak tanı konan ve ayrım gözetmeksizin baskılayıcı ilaç tedavileriyle tedavi edilen rahatsızlıkların birçoğunun aslında kökten bir kişilik dönüşümü ve spiritüel bir açılmanın sıkıntılı evreleri olduğunun farkına varılması önemlidir. Bunlar doğru biçimde anlaş1lır ve desteklenirse bu psikospiritüel krizler, duygusal ve psikosomatik iyileşme, dikkate değer psikolojik değişimler ve şuur evrimiyle sonuçlanabilir. ${ }^{11} \mathrm{Bu}$ şuur evrimini Gazali şöyle ifade etmektedir:

Bu müddet esnasında sayamıyacağım birçok sebeblerden dolayı bazan zevk ile bazan aklî delil ile ve bazı kere de kuvvetli imandan ileri gelen teslimiyet ile zarurî olarak bana zahir oldu ki, insan bedenden ve kalbden yaratılmıştır.

9 Gazali, El Munkızu Mined Dalâl, s.60-62.

10 Gazali, El Munkızu Mined Dalâl, s.85-86.

11 Grof, Stanislav, Geleceğin Psikolojisi, s .181 
Kalbden maksadım ruhtur ki o, marifetullah'ın (Allah'ı tanımağa mahsus yerin) mahallidir. Yoksa ölülerle, hayvanların müşterek bulunduğu et ve kandan ibaret olan kalb değildir. Bedenin sıhhatlisi vardır ki, insanın saadet ve selâmeti ona bağlıdır. Hastalıklısı da vardır ki, helakine sebeb olur. Kalb de böyledir. Onun da sıhhat ve selâmet hali vardır. İnsanlar için kurtuluş: «Ancak selim bir kalb ile Allah'1n huzuruna gelenlerdir.» buyrulmuştur. (Eş-Şuarâ Suresi, Ayet: 89) Kalbin bir hastalık hali de vardır ki insanın ebedî ve uhrevî helakine sebep olur. Nitekim Cenabı Hak Kur'ân-1 Kerîm' inde kalblerinden hasta olanlar hakkında: «Onların kalplerinde hastalık vardır.» buyurmuştur (Bakara Suresi, Ayet: 10). Allah'1 bilmemek helak edici bir zehirdir. Nefsin arzularına uyarak Allah'a isyan etmek o zehrin verdiği bir hastalıktır. Allah'ı tanımak onun diriltici panzehiridir.

Kalbin hastalığının izalesi ve sıhhate kavuşmasının yolu ancak ilâçlarla kabil olur. Nitekim bedenin tedavisi de ilâçlarla mümkündür. Bedenin tedavisi için kullanılan ilâçlar kendilerinde bulunan birçok hassa ile sıhhatin iadesine tesir ederler. Bunu insanlar akıl yolu ile idrâk edemezler. İlâçların tesirini nübüvvet hassası sayesinde eşyanın hassalarına vâkıf bulunan peygamberlerden öğrenmiş olan tabipleri taklit etmek icabeder.

Bunun gibi zarurî bilgi ile bana ma'lûm olmuştur ki, Peygamberler tarafından miktarları, hudutları belirtilen ibadet ilâçlarının tesirleri de akıllı kimselerin akıl sermayesiyle idrâk olunmaz. Bu hususta ibadetlerin hassalarını akıl yoluyla değil, Nübüvvet nuruyla idrak eden peygamberleri taklit etmek vacip olur. Peygamberler, kalp hastalıklarının tabipleridir. ${ }^{12}$

İlâçlar çeşitleri ve miktarları ayrı ayrı olan birtakım maddelerden yapılır. Bazı maddeler tartıda diğerlerinin iki misli olurlar. Miktarlarının çeşitli olması bir sir ve hikmete binaendir ki, hassalar bunu icap ettirir. Kalb hastalıklarının ilâçları olan ibadetler de nev'i ve miktarı çeşitli fiillerden meydana gelir. Meselâ, secde rükû'un iki misli; sabah namazı miktarca ikindi namazının yarısıdır. İşte bu, nübüvvet nurundan başka bir suretle muttali olunması mümkün olmayan hassalar kabilinden ilâhi bir sırdır.

İlâçların aslî cüzleri vardır ki, bunlar rükünlerdir. Bir de ilâçlarda tesiri sağlamak maksadıyla bazı maddeler ve tamamlayıcı unsurlar bulunur.

12 Gazali, El Munkızu Mined Dalâl, s.75-77. 
Bunun gibi nafileler ve sünnetler de ibadetlerin rükünleri olan farzların tamamlayıcısıdır. ${ }^{13}$

\section{Gazalinin Bilinç ve Denge Anlayışı ile Psikolojik Sağlık Arasındaki İlişki}

Gazali’ ye göre kendi bedensel varlığımız dâhil olmak üzere tüm görünen alem, bireyin gerçek kimliğini bulması için birer aracı rolündedir:

'Bil ki, gönül gayb âleminden gelmiş ve tekrar oraya dönecektir. Bu harap dünyaya ticaret ve ziraat için gelmiştir, zira dünya ahiretin tarlasıdır.

'Bil ki insanın iki şeye ihtiyacı vardır. İlki, kalbini helak olma sebeplerinden koruyup gıdasını temin etmek. Diğeri de bedenini helak edici şeylerden koruyup gıdasını temin etmektir. ${ }^{14}$ Gazali, kalbi bu sevgiye ulaştıran güzel davranışlara münciyat, kalbin mutsuzluğa, perişanlığa düşmesine sebep olan kötü ahlaka da mühlikat adını verir.

' Beden bağlı bulunduğu kalbin arzularını hazırlamak içindir. Çünkü beden fani, kalp ise bakidir.'

Bedenin kalbe hizmet için varolduğu hakikatini çok sade ve anlamlı bir benzetmeyle açıklar:

'Beden ile kalp arasındaki ilişki hacı ile deve arasındaki ilişki gibidir. Hac yolunda deve hacı içindir. Hacı deve için değildir. Ancak hacı ahiret için Kabe'ye varıncaya kadar devenin yemini ve diğer ihtiyaçlarını temin edip deve ile ilgilenmek zorundadır. Kabe'ye varınca onun sıkıntısından kurtulur. Ancak hacının yolda devesiyle ilgilenmesi lüzumu kadar olmalıdır. Çünkü bütün vaktini onun yem ve diğer ihtiyacını tedarik için harcarsa kafileden geri kalıp helak olur. Bunun gibi eğer insan bütün ömrünü bedenin kuvveti için sarf etse kendi saadetinden mahrum olur. ${ }^{15}$, Gazâlî'ye göre dünya varlıkları, amacı doğrultusunda kullanılmadığı takdirde insana varoluş amacını unutturmakta ve insanı helake (yıkılma, bitme, mahvolma, korku) sürüklemektedir:

'Hz. Peygamber, "Üç şey var ki helake götürür; Baş edilmeyen cimrilik, ardına düşülen kötü arzular ve kişinin kendini beğenmesi” buyurmuştur. Bilesin ki bu üç madde kalp hastalıklarının başlıcalarıdır ve bunların tohumunu büyüten toprak dünya sevgisidir. Bunda başarılı olursan diğer

13 Gazali, El Munkızu Mined Dalâl, s.76-77.

14 Gazali, Kimya-i Saâdet, Arslan Yayınları, İstanbul, 1979, s.64

15 Gazali, Kimya-i Saâdet, s.65. 
kalp hastalıklarından nasıl kurtulacağını da öğrenirsin. Bunları tedavi etmede başarılı olamazsan diğerlerini hiç tedavi edemezsin.'

Gazali, kalbin dünyaya bağlanması, hırs ve tutkularla acı çekmesine karş1, bir tedavi yöntemi olarak ölüm düşüncesini teklif eder. Dünya hayatının, menfaatlerin ve lezzetlerin geçici olduğunun farkındalığını yaşamanın en iyi yolu, ölüm hakikatinin hatırda tutulmasıdır. Ölüm bilinci, duygu ve düşüncelere denge getirir.

Yalom, güçlü ve etkin bir psikoterapi yaklaşımı ölümün farkında olma esasının üzerine inşa edilebilir' derken ${ }^{16}$, Gazali'nin bu yaklaşımıyla paralel bir tedavi önerisinde bulunur. Ölüme yaklaşıp geri dönen, bir anlamda ölüm deneyimi yaşayan insanlar hakkındaki izlenimlerini, "pek çokları daha önce olduklarından daha şefkatli ve insan yönelimli hale gelişlerini, 'önceliklerin yeniden değerlendirilmesini' tarif etmişlerdir' şeklinde anlatır. ${ }^{17}$

Gazali, mühlikat dediği, insanı helake götüren sebepler olarak sıraladığ1, dünyayı tercih ve onu kutsama, aşırı gıdalanma, cinsel şehvet, cimrilik, şanşöhret tutkusu, riya, dili tutamama, öfke, kin, kibir, haset gibi duyguların insana Allah tarafından verilmiş ve asıl itibariyle kötü olmayan, kullanıma bağlı olarak insanın kendine zararlı hale getirdiği duygular olduğunu söyler. ${ }^{18}$

Amacı dışında çalışan organ hasta olur. Psikolojik problemlerin sebebi de aklın ve kalbin amacı dışında kullanılmasıdır. Gazali’ye göre, kötü karakter özelliklerinin oluşmasının temelinde diğer insanların kanaatlerine göre davranma anlayışı yatmaktadır. Oysa davranışları diğer insanların kanaatleri değil, prensipler tayin etmelidir.

Diğer insanların kanaatlerine göre davranmanın insan psikolojisi üzerinde olumsuz tesirleri olduğu konusu Fromm'un eserlerinde de incelenmiştir:

Uyumlu insan, kendini başkalarınca kullanılabilir bir araç haline getirmiş ve hoşa gitmek çabasıyla rolünü değiştirmeye her an hazır olan birisidir. Çabalarında başarılı olunca, duyduğu ve o da belli bir düzeyde kalan güvenlik duygusunun etkisiyle sevinir. Ama kendi en yüksek özüne ve insancıl değerlere olan ihaneti, onun içinde bir boşluk ve güvensizlik yaratır. Başarı için olan uğraşısı biraz ters gitti mi, korku ve anlamsızlık bu kimsenin karşısına dikiliverir. Gerçi işler yolunda gittiği zamanlarda

16 Yalom, Irvin, Varoluşçu Psikoterapi, Kabalcı Yayınevi, İstanbul, s.49.

17 Yalom, Irvin, Varoluşçu Psikoterapi, s. 60.

18 Gazali, Kimya-i Saâdet, s.450-490. 
bile bu kişiler mide şikâyetleri, kalp rahatsızlıkları ve diğer psişik nedenli hastalıklar ile boğuşarak hep kendilerinden öderler başarının bedelini. İçsel güçlülük ve bütünlüğüne ulaşmış bir kimse ise, belki vicdanının sesini hiç duymadan yaşayan komşusu kadar parlak başarılar elde edemeyebilir. Ama duyacağ 1 iç huzuru, karar verebilme ve nesnel olabilme özellikleri ile bu kimse, kaderinin değişikliklerinden daha az etkilenecek, giriştiği kendine uygun işlerde daha başarılı olacak ve herkesin ilgisini toplayacaktır. ${ }^{19}$

Gazali, psikolojik problemlerin temel kaynağı olarak düşündüğü, azaların yaratılış amacına uygun kullanılmaması konusunu şöyle açıklar:

'Bil ki, bedenin azalarının her biri, kendisine mahsus bir fiil için yaratılmıştır.

'Bu bakımdan elin hastalığı, kendisine çalışmanın zor gelmesidir. Gözün hastalığı, görmenin kendisine zorlaşmasıdır. Kalbin hastalığı da yapması için yaratılmış olduğu fiilin yapılmasının kendisine zor gelmesidir. Bu fiil de ilim, hikmet, mârifet, Allah sevgisi, Allah'a ibâdet, Allah 'in zikrinden zevk duymak ve Allah'ın zikrini diğer şehvetlere tercih etmektir. ${ }^{20}$

Nitekim Allah şöyle buyurmuştur:

Ben insanları ve cinleri, ancak bana ibâdet etsinler diye yarattım.(Zâriyât suresi,56)

Açıkça ayette geçen "a-b-d" fiilinin anlamlarını incelediği doktora çalışmasında "abd" kelimesinin çalışmak, üretmek, yeteneklerini yaşamak, kendini gerçekleştirmek olduğunu açıklamaktadır. İnsanın ruhuyla ve bedeniyle varoluşunu yaşaması ve sahip olduğu güçleri eyleme dönüştürmesi önemlidir.

Gazali' ye göre her âzâda bir fayda vardır. Kalbin faydasi; hikmet ve mârifettir. İnsan nefsinin özelliği, hayvanlardan ayrılmasına sebep teşkil eden şeydir. Çünkü Âdemoğlu hayvanlardan yemek, cinsel güç, görme ve bunlara benzer özelliklerle ayrılmaz. Aksine eşyanın hakikatini bilmekle ayrılır. $\mathrm{Bu}$ bakımdan kişi her şeyi bilip Allah'1 bilmediği takdirde sanki hiçbir şey bilmiyor demektir. Allah'1 bilen bir kimse Allah'1 sever.

De ki: Babalarınız, oğullarınız, kardeşleriniz, karılarınız, soylarınız, kazandığınız mallar, geçersiz olmasından korktuğunuz ticaret, hoşunuza giden meskenler, size, Allah' tan, Rasûlü'nden ve onun yolunda cihaddan daha sevgili ise, artık Allah'ın emri gelinceye kadar bekleyin! Allah fâsıklar toplulu-

19 Fromm, Erich. Psikanaliz ve Din, Arıtan Yayınevi, İstanbul, 1993, s. 88

20 Gazali, İhyâu Ulûmi’d Dîn, Aslan Yayınları 1980, C.3-4. 
ğunu hidayete erdirmez (Tevbe suresi,24). Bu bakımdan nezdinde Allah' tan daha sevimli bir şey bulunan bir kimse hastadır. ${ }^{21}$

Kalp, sağl1klı bir yaşam için dengeye ihtiyaç duyar. Bedende dengeli beslenme, dengeli hareket, egzersiz ve diyet gerekir. Bunlar yoksa kalp zamanla rahatsızlanır. Gazali duygularda ve davranışlarda dengeye itidal, aşırısına ifrat, azına tefrit adını verir. Duyguların itidalli kullanılmayışı kalbi olumsuz etkiler. Sağlıklı insanda bulunması gereken, duygunun itidal boyutudur.

Mesela Hikmet sıfatı dengede olunca ondan, tedbir, parlak düşünce, amellerin incelikleri ve nefsin gizli afetlerini tanıma konusunda güzel anlayışlar ortaya çıkar. Hikmetin ifrat hâlinden; hile, aldatma, kurnazlık ve benzeri huylar ortaya çıkar. Hikmet noksan olunca (tefrit), dalgınlık, cahillik, ahmaklık ve delilik ortaya çıkar. Gazap(öfke) kuvvetine gelince; gazabın itidal(dengeli) hâline şecaat denir. Şecaatten; cömertlik, darda kalanlara yardım, kinini tutma, sözünde durma gibi güzel huylar ortaya çıkar. Gazabın ifrat(aşırı) derecesi vardır; ondan, kibir, kendini beğenme, aşırı kızgınlık ve benzeri kötü huylar ortaya çıkar. Gazabın tefrit(noksan) ve gevşek derecesi vardır; ondan da, düşüklük, zillet, korku ve içe kapanıklılık meydana çıkar. Gerçi, bu derecede insan, gerekli hakkını alır, fakat genelde zillet hâli yaşar. Şehvet kuvvetine gelince, onun itidal/dengeli hâline iffet denir. İffetten, cömertlik, sabır, veraşüpheli şeylerden çekinme, insanlara yardım ve kimsenin elindeki mala göz dikmeme gibi güzel huylar ortaya çıkar. Şehvetin ifrat/aşırı hâlinde, hırs, mala ve keyfine aşırı düşkünlük gibi kötü huylar ortaya çıkar. Onun tefrit/noksan hâlinde ise, haset, küfür, kınayıp ayıplama gibi kötü huylar ortaya çıkar.

Güzel ahlâkın temeli, hikmet, şecaat, iffet ve her birisinin mükemmel hâli olan adalettir. Yergi ve övgü, korku ve ümit, evlilik ve bekârlık, zenginlik ve yoksulluk, harcama ve tutumluluk gibi karşı1 durumlar, imkân veya imkânsızlıklar ne iyidir ne de kötüdür. Çünkü bunları iyi veya kötü kılan arkalarındaki niyet, beklenti, amaç ya da düşüncedir. Niyet ve bilinçlilik Gazali için çok önemli kavramlardır.

İnsanın sağlığına kavuşmasının işaretlerini açıklarken kişinin tedavi ettiği illete bakmasının önemli olduğunu belirtir. Eğer cimrilik hastalığını tedavi ediyorsa, bu hastalığın öldürücü ve Allah' tan uzaklaştırıcı bir hastalık oldu-

21 Gazali, İhyâu Ulûmi'd Dîn, C.3-4. 
ğunun farkında olmalıdır: Bunun tedavisi ancak mal vermek ve infak etmekle mümkün olur. Fakat kişi bazen malı israfçı olacak derecede verir. Bu sefer israf da hastalık olur. Cimrilik hastalığının tedavisinde de böylece israf ile cimrilik arasındaki normal durumu elde etmek gerekir ki ifrat ve tefrit taraflarından uzak olup orta yolun tam üzerinde bulunsun. ${ }^{22}$,

Aslında ahirette kıldan ince kılıçtan keskindir diye tasvir edilen sırat, insanın dünya hayatında duygu ve davranışlarında yakalayabildiği itidaldi.

Gazali insan için her zaman denge halinde bulunmanın zorluğunu kabul eder. Belki de duygularda dengeyi yakalama gayreti hepsinden değerlidir. Dosdoğru yol üzerinde iolmak oldukça zordur. Fakat istikametin hakikatine gücü yetmese dahi, onun yakınına varmak için var kuvvetiyle çalışmalıdır. ${ }^{23}$

Gazali Kimya-yı Saadet adlı eserinde kişinin batınında dört sıfat olduğunu ve kişi bunları bilmedikçe, kendi saadetini bilmeye muktedir olamayacağını belirtmiştir. Bunlar: hayvansal özellik (hayvanların gıdası, yem yemek, uyumak ve çiftleşmek), yırtıcı özellik (öldürme, hiddet ve intikam güdüsü), şeytani özellik (kişiyi doğru yoldan Allah’tan uzaklaştırmak), meleklik özelliği (çarpık özellikleri kendisinde barındırmaz. Melek özelliği taşıyan bir birey, kendisini tanımaya çalışır, niçin dünyaya geldiğini, nasıl yaşaması gerektiğini, insanlara nasıl davranması gerektiğini düşünür, bir bütün olarak kendisinin bilincindedir). ${ }^{24}$

$\mathrm{Bu}$ özellikleri bilen, hangisinin kendinde daha fazla olduğunu anlayan insan, özünü bilmeye bir adım daha yaklaşmış insandır. Melekuti özelliklerini arttırmaya ve diğer özelliklerini aza indirmeye çalışan insan hikmet gözüyle bakmaya başlar ve özünü anlar. Özünü bilen ise karakteri oturmuş ve ruhsal bakımdan sağlıklı insan demektir. Kısaca, sağlıklı insan, kendi özündeki Şeytani ve Melekuti yanların farkında olan ve onlara karşı iradesini kullanabilen insandir.

Gazali ye göre ruhsal anlamda en sağlıklı insan Hz. Muhammed'dir. Bu düşüncesini şu hadis-i şerifle aktarmıştır:

"İnsanoğlundan her ferdin içinde bir şeytan vardır. Hatta benim dahi vardır.

Ancak Allah Teâlâ beni onlara muzaffer, onu da bana mağlup eyledi. Öyle

22 Gazali, İhyâu Ulûmi'd Dîn, C.3-4.

23 Gazali, İhyâu Ulûmi'd Dîn, C.6, s.153-155.

24 Gazali , Kimya-i Saâdet, s.27 
ki, bende hiçbir surette kötülük yaptırma imkânı bulunmadı." Gazali ahlakı dünyada ve ahirette mutluluk için esas olarak görür. Ona göre ahlak, kişinin ruhi sıkıntılarına da bir çare ve devadır. Gazali'ye göre insanı kurtuluşa götüren yollar, diğer bir tabirle sağlıklı insanda bulunan vasıflar şunlardır:

- Tövbe

- Sabır ve Şükür

- Korku ve Reca (İbadette ümid)

- Fakirlik ve Zühd

- Niyet, S1dk ve İhlâs

- Muhasebe ve Murakebe

- Tefekkür

- Tevhid ve Tevekkül

- Sevgi, Şevk ve Rıza

- Ölümü Hatırlamak ${ }^{25}$

\section{Gazali' ye göre tedavi süreci:}

1. Önce hastalığı kabul,

2. Sonra tedaviye yönelik ilk aşamada irade ile doğru davranmak,

3. Zamanla doğru davranışın karakter halini alması

4. Bu süreçte sabırlı olmak,

5. İyileşme konusunda kararlı olmak. ${ }^{26}$

Gazali'nin tedavi süreci olarak sunduğu aşamalar, tövbe süreciyle benzerlik göstermektedir.

Tövbe etmek, bir halden başka bir hale dönüşmeyi içerir ve dört aşamadir:

1. Farkındalık

2. Kendini affetme

3. İnsanın öz bilincinden doğan kendine ve başkalarına yararlı eylemler üretme

4. Kararlılık ve kalıc1lık ${ }^{27}$

Tövbe etmek; yenilemektir, eskiyi bırakıp bulunduğu anı ve geleceği tasarlamaktır. Bunun için kişinin önce hastalığını kabul etmesi gereklidir. Has- 
talığını kabul eden insan farkındalık aşamasını başarıyla geçmiş olur. Sonra tedaviye yönelik ilk aşamada irade ile doğru davranmak gereklidir. Sabırla devam eden iradi kararlılık bir müddet sonra kişinin karakteri halini alır.

Tövbe etmek, hastalığa koyulan tanı gibi ne kadar erken olursa o kadar faydalı ve etkili olur. Çünkü tövbeyi erteleyen kimse, bir ağacı kökünden sökmek zorunda olan ve bunun büyük bir zahmetten sonra sökülebileceğini anlayıp da "ben bu ağacı bir sene daha bırakayım. Ondan sonra gelip sökerim!" diyen kimseye benzer. Oysa ağacın, gittikçe kök saldığını ve kendisininse ihtiyarladıkça zayıfladığını çok iyi bilir. Bu bakımdan dünyada bu kimsenin ahmaklığından daha büyük bir ahmaklık tasavvur olunamaz; zira bu kişi kuvvetli olduğu sırada yenemediği zayıf bir şeyi yenmek için kendisinin zayıf düştüğü, onun da kuvvetleneceği bir zamanı beklemeye başlamıştır. " Ey müminler, kusurlarınızdan Allah'a tövbe ediniz ki, felah bulasınız." (Nur Suresi, 31) Hadis-i şerifte: "Günahtan tövbe eden kimse, günah işlememiş gibidir." 28

Tövbe etmek günümüzde geçmişi ile barışık olmayan, hatalarını unutamayan kişilerin en güzel kurtuluş reçetesidir. Çünkü tövbe etmek, kendini affetmektir. Gazali’nin bahsettiği ilim, hal, amel döngüsü günümüz psikoloji biliminin en popüler terapi yöntemlerinden olan Kognitif -Bilişsel Psikoloji bakış açısının özünü aktarmaktadır. Bilişsel Davranışçı terapi, bireyin bilgi ve düşüncelerinin davranışlarını ve davranışlarından doğan sonuçları değiştireceği tezine dayanır. Ve terapinin amacı hastanın düşünce yapısını değiştirmektir. ${ }^{29}$ $\mathrm{Bu}$ durumda psikolojik gerginlikler ve endişeler son bulabilir. Bu da hal tavır ve davranışlarına yansıyacaktır.

\section{Kaynakça}

AYTEN, Ali, “Transpersonel Psikoloji Nedir Ne Değildir”, Din Psikolojisi, İz Yayıncilık, İstanbul 2010.

ÇAMDİBİ, H. Mahmut, Şahsiyet Terbiyesi ve Gazali, Han Neşriyat, İstanbul, 1983.

FROMM, Erich. Psikanaliz ve Din, Arttan Yayınevi, İstanbul, 1993.

GAZALİ, El Munkızu Mined Dalâl, Çağaloğlu Yayınevi, 1984.

28 Gazali, Kimya-i Saâdet, s.702.

29 Kramer, Geoffrey; Douglas, Bernstein; Phares, Ricky, Inroduction to Clinical Psychology, 7. Edition, pp.282-293. 
GAZALİ, İhyâu Ulûmi'd Dîn, Aslan Yayınları 1980.

GAZALİ, Kimya-i Saâdet, Arslan Yayınları, İstanbul, 1979.

GROF, Stanislav, Geleceğin Psikolojisi, Ege Meta Yayınları, 2000, İzmir.

KRAMER, Geoffrey; Douglas, Bernstein; Phares, Ricky, Inroduction to Clinical Psychology, 7. Edition.

ÖZDOĞAN, Öznur. İsimsiz Hayatlar, Özdenöze Yayınevi, 2009.

PALMER, Helen, Ruhun Aynası Enneagram'a Yansıyan İnsan Manzaraları, Kaknüs Yayınları, 2006.

YALOM, Irvin, Varoluşçu Psikoterapi, Kabalcı Yayınevi, İstanbul. 